\title{
Hydraulic fracturing in cave mining: Opportunities for improvement
}

\author{
R Rimmelin The University of Queensland, BHP, Australia \\ G Chitombo The University of Queensland, Mining3, Australia \\ E Rojas CODELCO, Chile
}

\begin{abstract}
Hydraulic Fracturing (HF) in cave mining is commonly used in competent rock under high stresses and seismic conditions, to manage risks associated with induced seismicity and cave propagation. The HF process is done using up holes drilled from the undercut level (e.g. El Teniente-Codelco) or down holes from an upper level (e.g. Newcrest mining). Discrete fractures assumed to be in the order of 20 to $40 \mathrm{~m}$ in diameter are then created every $1.5 \mathrm{~m}$ or $2.5 \mathrm{~m}$ along the drill holes, using water at higher pressures. In comparison, other industry experience such as Petroleum, HF is based on similar principles in terms of the drill hole alignment with the principal stresses and the use of water at high pressures, but more efficient during the process of the creation of the network of fractures. The network of fractures thus created covers a volume rather than discrete fractures and could be as long as $100 \mathrm{~m}$. Currently, petroleum HF process is carried out from the surface down to 3,000 $\mathrm{m}$ in depth. Also, the use of additional materials such as "sand" to improve the propagation of fractures is another example of Petroleum practices that can be used in Cave Mining. Another point of discussion relies on the current practices in Cave mining, in which, stress anisotropy is not considered to address important topics such as efficiency of the HF process and spatial distribution of the HF holes, for a better coverage of the rock mass. Hydraulic Fracturing is increasingly becoming an essential enabling tool in deep hard rock cave mining, and some of the current HF practices used in the Petroleum industry offer an opportunity to improve the cave mining HF processes. This paper proposes the use of known rock mechanics principles for the cave mining industry to adopt practices used in the Petroleum to achieve the intended outcomes from HF as currently used in cave mining.
\end{abstract}

\section{Introduction}

Pre-conditioning is the process to induce in situ fractures into a rock mass, with the purpose to modify its geomechanical properties and potentially enable a higher cave performance. Pre-conditioning has been applied using drillholes to inject water (or viscous fluids) at high pressure to produces the fracturing. Most elements used to fracture rock are explosives and water injection, and more recently, liquid natural gas. The pre-conditioning in cave mining has been shaping the caving mining method along the years (see Figure 1).

The history of cave mining shows different types of application of pre-conditioning, using confined blasting, hydraulic fracturing or a combination of both. The first case of application in cave mining was Northparkes, in which hydraulic fracturing was used for enhanced cave propagation and the application of blasting preconditioning to enhance slot performance (Figure 2).

El Teniente mine has widely applied hydraulic fracturing for preconditioning for over 15 years, currently being an integral part of their mining method (Brzovic \& Gonzalez 2019). Currently, hydraulic fracturing is applied to create flat fractures every $1.5 \mathrm{~m}$ from the undercut upwards to the rock mass, and downwards to the production level, jointly with a conventional undercutting (Figure 3). 


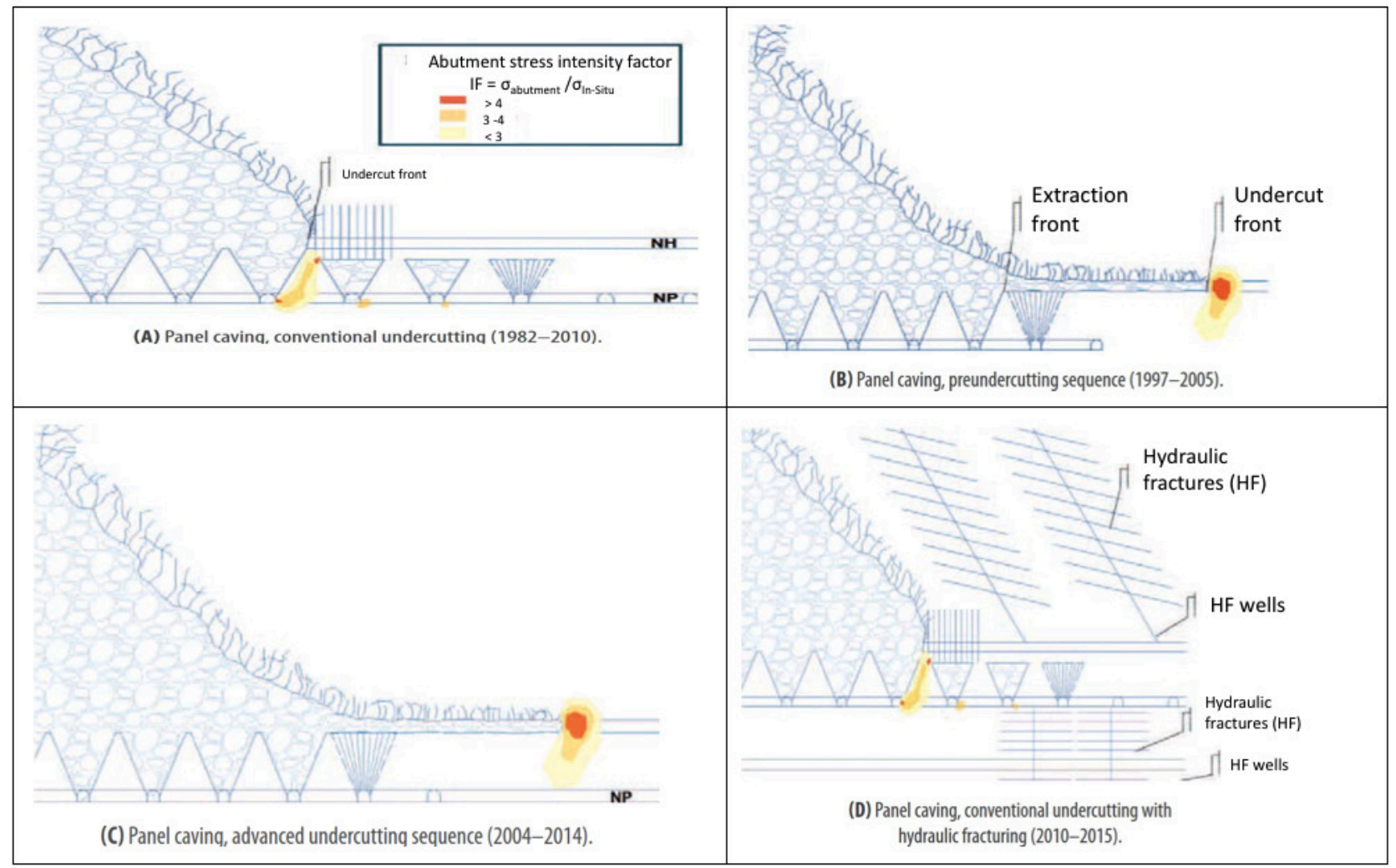

Figure 1 Evolution of exploitation mining method at El Teniente mine until current application of preconditioning (Pardo \& Rojas 2016)

Newcrest developed the concept of intensive pre-conditioning based on the use of hydraulic fracturing from an upper level (above the undercut level), to then apply confined blastings along lower drillholes from the undercut level. This application allowed increasing the in situ fracturing with the combination of the two techniques (Figure 4).

Regardless the specific application, pre-conditioning has been developed over the application of hydraulic fracturing techniques. In this regards, Petroleum industry has developed different applications of hydraulic fracturing using not only water but also viscous fluids in conjunction with proppants like sand. Nevertheless, the Petroleum's business objective is the increasing of in situ permeability, with the purpose of connecting the wellbores and the resource (oil). In this regards, there are two general types of application: vertical wellbores stimulation and hydrofracturing of shale unconventional reservoirs. Vertical wellbores stimulation application is used in conventional Petroleum operation, in which hydraulic fracturing generates axial fractures, to improve connectivity along the hole. On the contrary, hydraulic fracturing is used in unconventional shales reservoirs (and natural gas) to generate multiple fractures perpendicular to horizontal wellbores, to increase the permeability and connection with the resource (see Figure 5). 

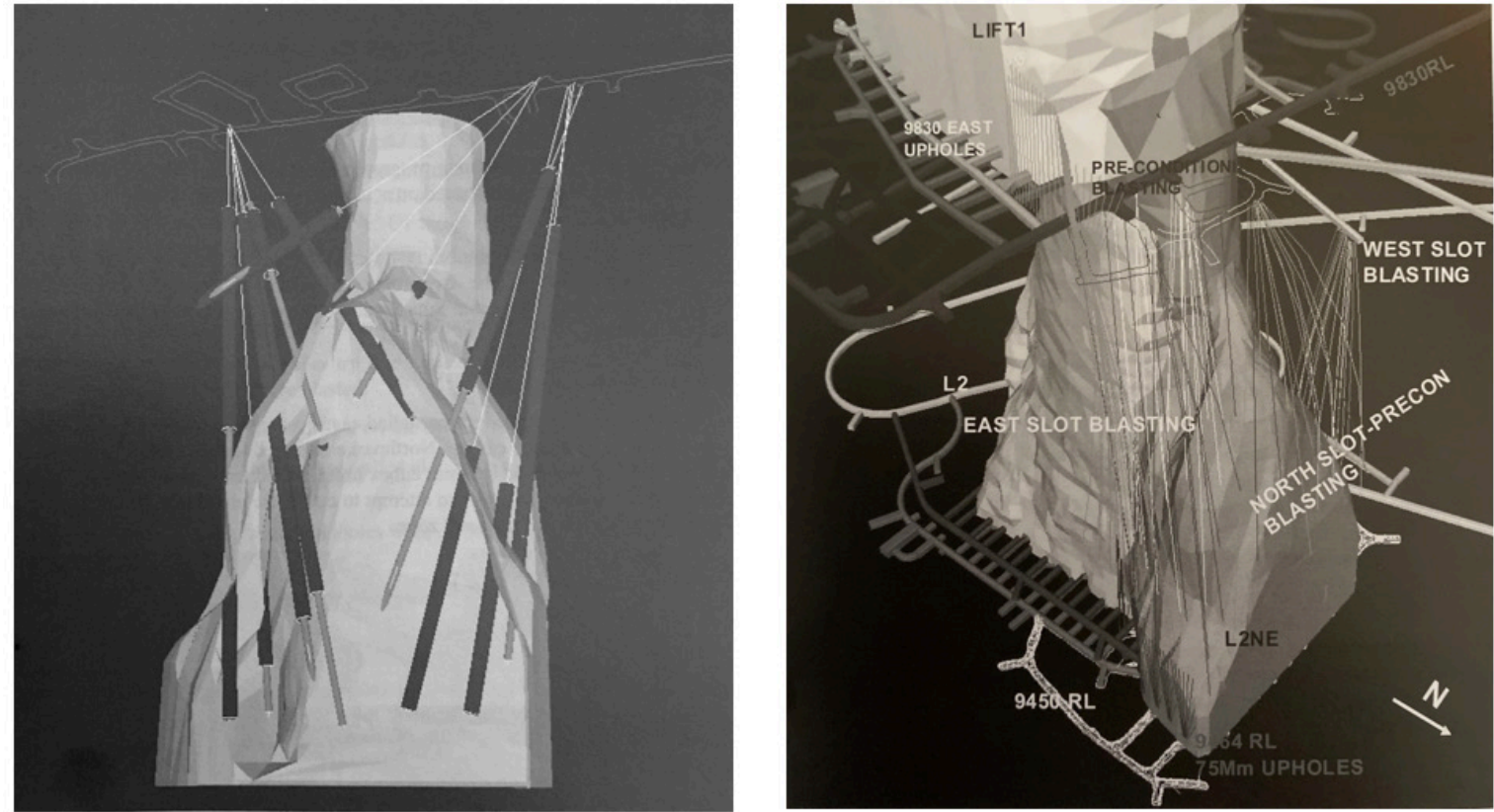

Figure 2 Pre-conditioning implemented in Lift 2 North extension (L2NE) block cave based on hydraulic fracturing and blasting along slot margin in Northparkes mine, Rio Tinto (Talu et al. 2010)

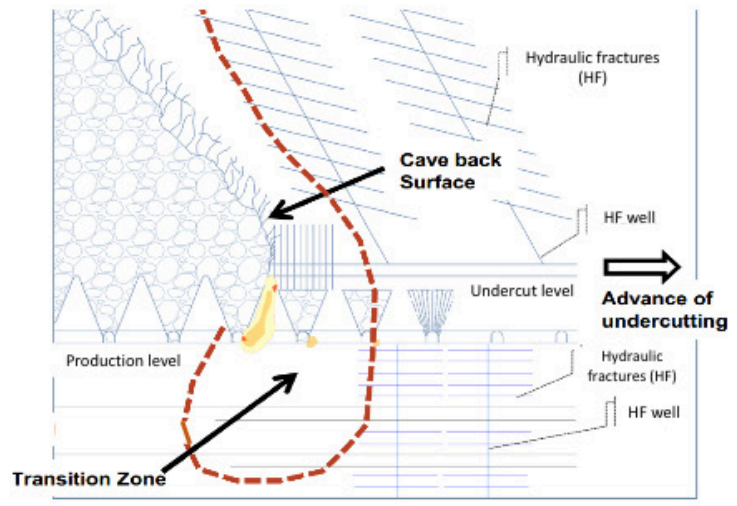

\section{$>$ Hydrofracture Basis}

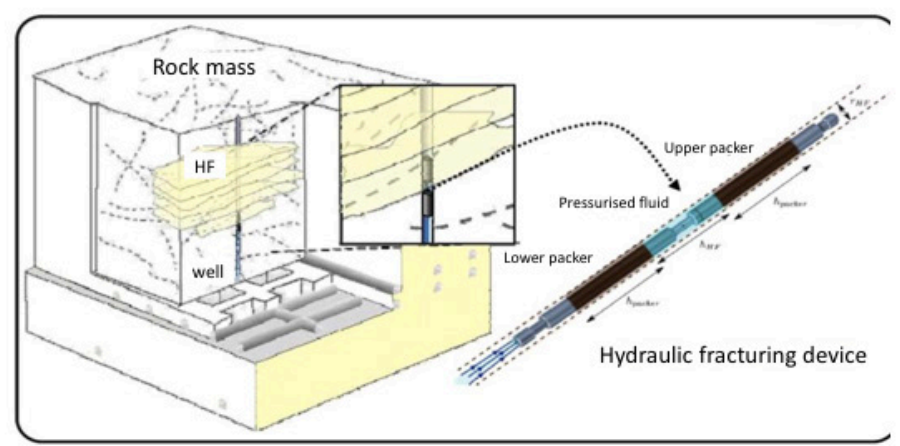

Figure 3 Scheme of Conventional Panel Caving with hydraulic fracturing at El Teniente mine, Codelco (Rojas 2018)
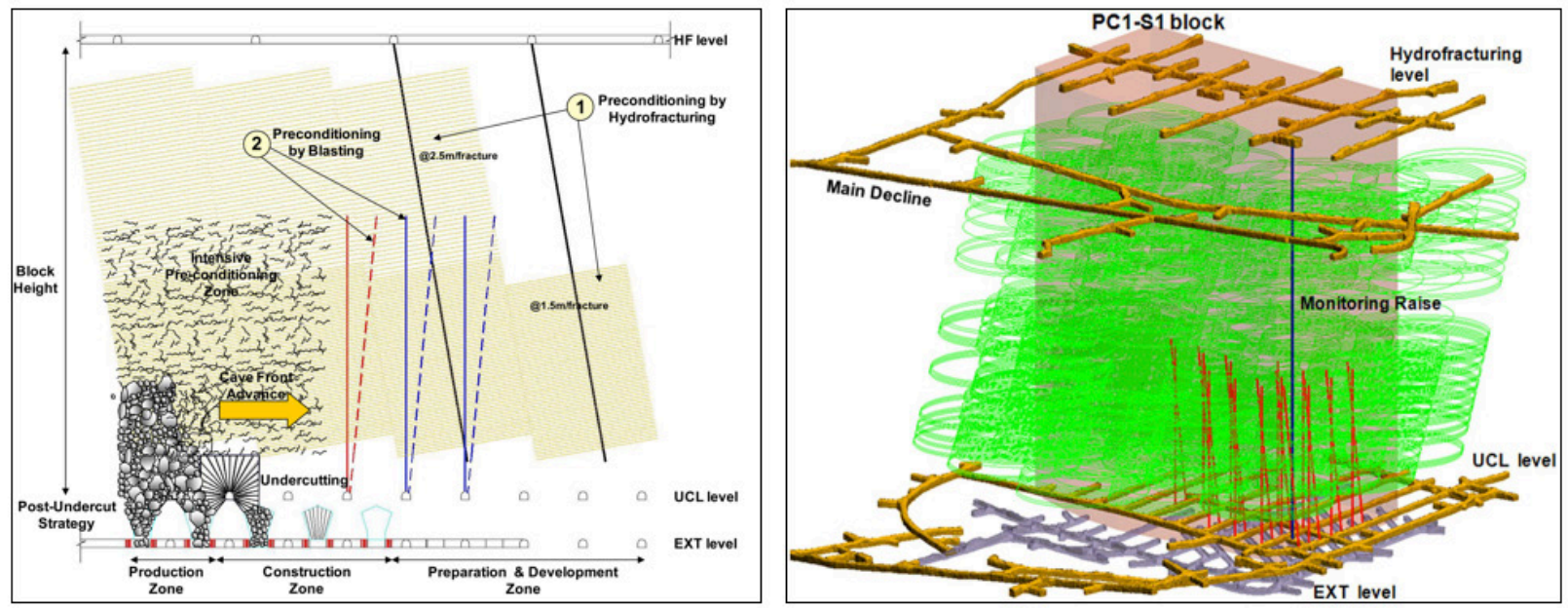

Figure 4 Intensive pre-conditioning (combination of hydraulic fracturing and confined blasting) in Cadia East mine proposed for PC1 and PC2 cave blocks, Newcrest Mining (Catalan et al. 2017) 

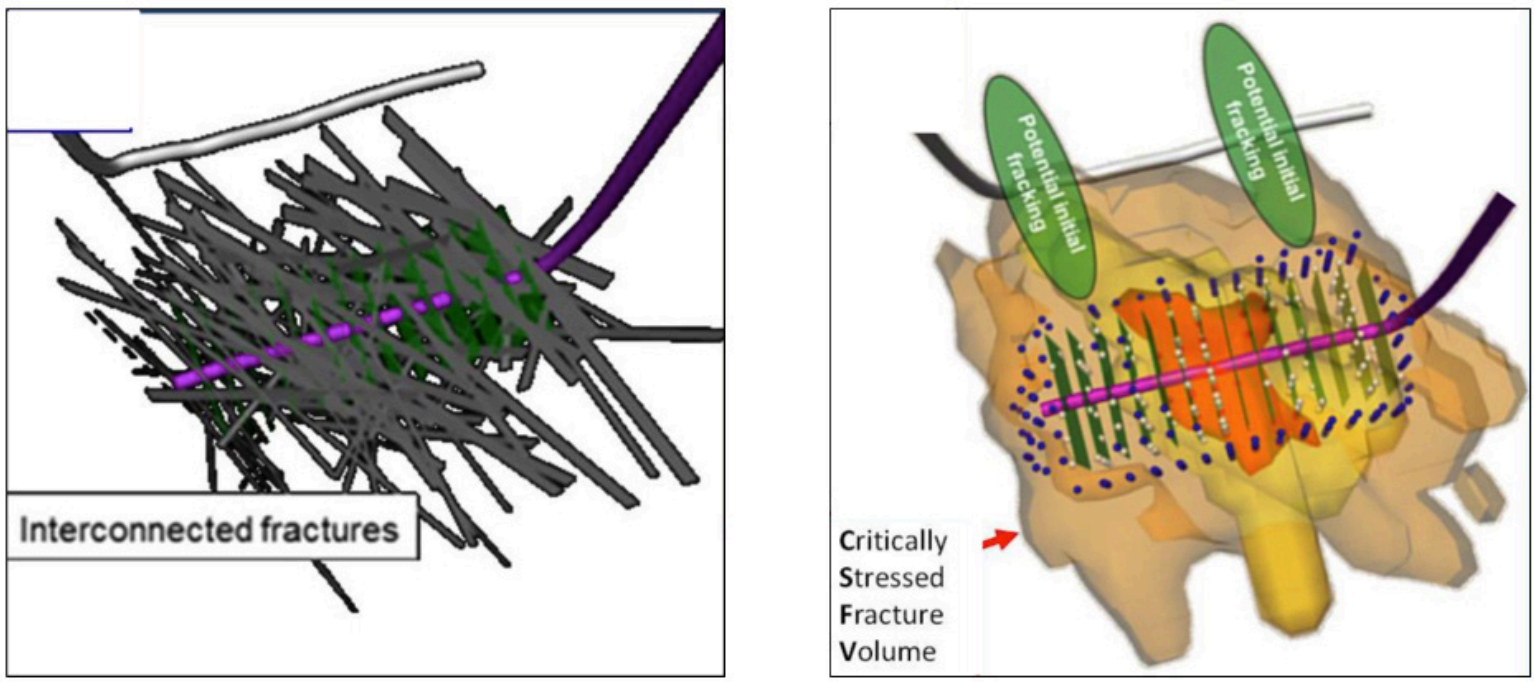

Figure 5 Multistage hydraulic fracturing applied to horizontal wellbores in Haynesville Shale, BHP Billiton (Bayer et al. 2016)

It is evident that mining followed petroleum application of the hydraulic fracturing concepts, but not taking advantage of those to adapt the process to be more efficient and effective in the context of cave mining. Table 1 shows a summary of the applications in cave mining and petroleum but also the objective related to each extraction method. While petroleum engineering application focus on increase permeability, cave mining has exhibited evidence of: better seismic response (Johnson \& Martinsson 2018), better cave propagation (Sainsbury et al. 2018) and better fragmentation size (Brzovic \& Gonzalez 2019).

Table 1 Summary of pre-conditioning application in cave mining and petroleum

\begin{tabular}{|c|c|c|}
\hline Industry & Extraction method objectives & Pre-conditioning application \\
\hline \multirow[t]{3}{*}{ Cave mining } & Better seismic response & \multirow{3}{*}{$\begin{array}{l}\text { Confined blasting, Hydraulic } \\
\text { fracturing, Intensive pre- } \\
\text { conditioning }\end{array}$} \\
\hline & Better cave initiation/propagation & \\
\hline & Reduce fragmentation size & \\
\hline Petroleum & $\begin{array}{l}\text { Increase reservoir permeability for enhanced oil } \\
\text { recovery }\end{array}$ & $\begin{array}{l}\text { Hydraulic fracturing (water/ } \\
\text { oil and proppants) }\end{array}$ \\
\hline
\end{tabular}

\section{Opportunities to optimise a hydraulic fracturing design}

The application in petroleum engineering and the understanding of the mechanical process of hydraulic fracturing, is key to identifying opportunities for a successful implementation in cave mining. In this regard, application aspects of using water, other type of fluids and proppants, provide a broader range of combination and designs, to produce different effects of fracturing. Additionally, there are other aspects such as geotechnical environment, fracture re-orientation and stress shadow, which potentially affect the performance of the process in the context of current application in cave mining.

This work presents the key aspects to be considered for a hydraulic fracturing process in cave mining and petroleum engineering, and what the opportunities are to improve cave performance.

\subsection{Key aspects on hydraulic fracturing in cave mining and petroleum}

The result and type of in situ fracturing depends on several aspects, that must be described but also understood in terms of the impact in a hydraulic fracturing implementation in both cave mining and petroleum engineering. For each aspect can be seen a positive or negative impact on performance, which is related to the extraction method and specific implementation. 


\subsubsection{Geotechnical environment}

In terms of the geotechnical environment, stress regime is one the key elements that address fracture propagation in the far field. The fractures are produced by injecting a fluid, usually water, into a drillhole to initiate the fracturing. Independently of how the fracture was initiated, eventually it will propagate aligned with the major principal stresses (Deeg 1998). In the case of shale reservoirs, the major principal stress $\left(\sigma_{1}\right)$ is usually vertically oriented, and minor/intermediate principal stresses ( $\sigma_{3}$ and $\sigma_{2}$ respectively) are constrained, based on hydraulic fracture tests. Then, hydraulic fractures tend to be vertically, independently the wellbore orientation (see Figure 6).

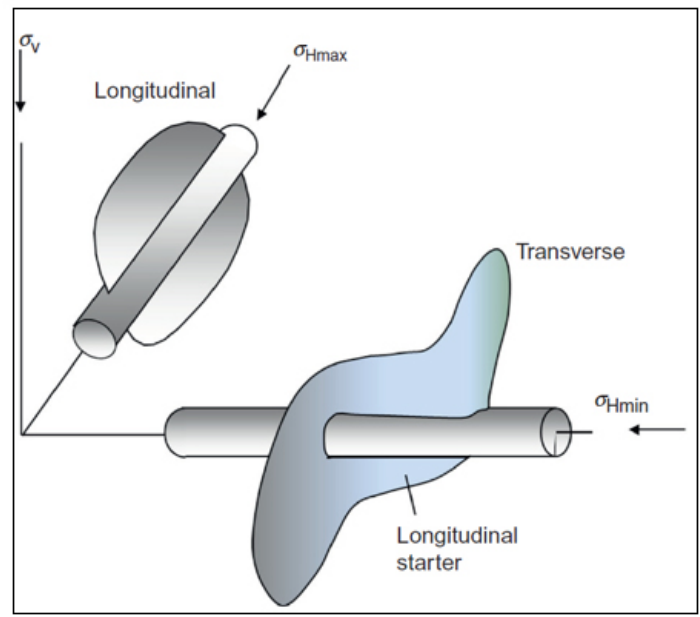

Figure 6 Longitudinal and transverse hydraulic fracture in deviated wellbores (Yew \& Weng 2015)

In comparison, Figure 7 shows that $\sigma 1$ is usually horizontal in most of cave mines in which a preconditioning technique has been applied (Hormazabal et al. 2010; Catalan \& Suarez 2010; Windsor et al. 2006; Jeffrey et al. 2010). This means that hydraulic fractures tend to propagate horizontally.
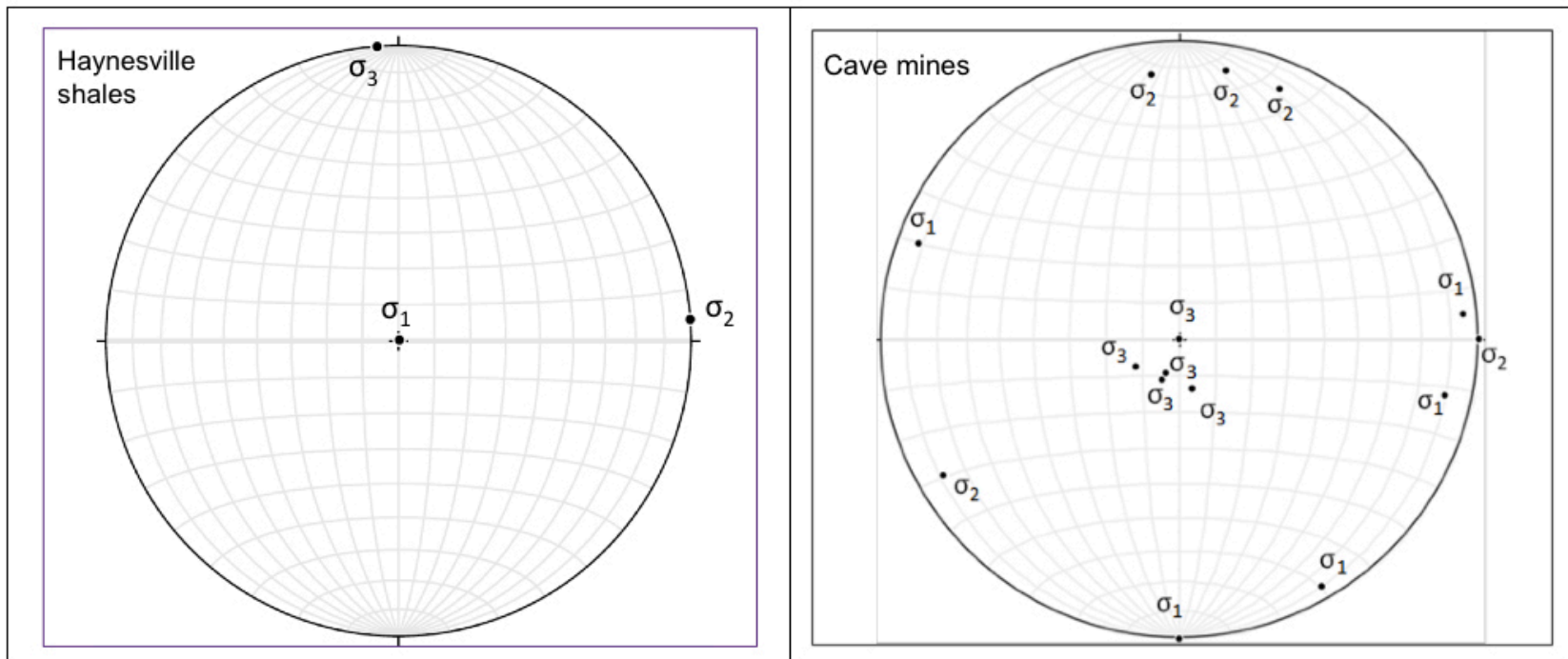

Figure 7 In Situ Stress regime in cave mines with application of hydraulic fracturing, compared to a Haynesville shales reservoir. Cases of El Teniente, Cadia East, Northparkes and Chuquicamata (Hormazabal et al. 2010; Catalan \& Suarez 2010; Windsor et al. 2006; Jeffrey et al. 2010)

In terms of strength parameters such UCS, it is also possible to see differences between Petroleum (sedimentary deposits) and cave mining (porphyry copper deposits). A representative rock strength from Texas Gulf Coast, hosting many petroleum reservoirs applying hydraulic fracturing, shows a UCS range of $22 \mathrm{MPa}$ to $85 \mathrm{MPa}$ (Zham \& Enderlin 2010). In comparison, most porphyry copper deposits hosted in primary rock shows a range of $89 \mathrm{MPa}$ to $144 \mathrm{MPa}$ (Hormazabal et al. 2010; Catalan \& Suarez 2010; Windsor et al. 2006; Jeffrey et al. 2010). 
In Situ stress field and rock strength impact the performance of hydraulic fracturing, in terms of requirements for breakdown pressure $(\mathrm{Pb})$ needed to initiate fracturing. Table 2 shows a summary of breakdown pressures for cave mines and a case of shale reservoir, using empirical information, poroelastic assumption (Detournay \& Cheng 1993) and elastic assumption (Jaeger et al. 1976). Based on field studies, a high pore pressure value is considered for Haynesville, and a poroelastic parameter (囚) typical for sandstones (Bayer et al. 2016).

Given that poroelastic parameter ranges between 0.0 and 0.5 , cave mines forced to use the maximum value in the upper part of this range to approach the field result. Based on this, an elastic estimation is recommended for cave mining, which it was useful to estimate the expected breakdown pressure for deeper areas of El Teniente, as part of this exercise. In addition, in situ high stress field (Windsor et al. 2006) in deeper areas of El Teniente, is comparable with Haynesville shale reservoir In Situ stress field. Regardless breakdown pressure for El Teniente is higher (more than 2 times) than Haynesville, mainly explained because of pore pressure conditions and poroelastic behaviour. This result is potentially important to understand how geotechnical environment can affect the implementation and performance of a hydraulic fracturing process in cave mining.

Table 2 Summary of geotechnical environment in pre-conditioning application in cave mining and petroleum (Hormazabal et al. 2010; Catalan \& Suarez 2010; Jarufe \& Vasquez 2008; Jeffrey et al. 2010; Zhang \& Yin 2017)

\begin{tabular}{|c|c|c|c|c|c|c|c|c|}
\hline & & & & \multicolumn{4}{|c|}{ Cave Mining } & \multirow{2}{*}{$\begin{array}{c}\text { Shale } \\
\text { reservoir } \\
\text { Haynesville }\end{array}$} \\
\hline \multicolumn{2}{|c|}{ Parameter } & Symbol & Unit & $\begin{array}{l}\text { Cadia } \\
\text { East } \\
\text { PC1 }\end{array}$ & $\begin{array}{c}\text { Northparkes } \\
\text { L2NE }\end{array}$ & $\begin{array}{c}\text { El Teniente } \\
\text { Reservas } \\
\text { Norte-Dacita }\end{array}$ & $\begin{array}{c}\text { El Teniente } \\
\text { New Mine } \\
\text { Level }\end{array}$ & \\
\hline \multicolumn{2}{|c|}{$\begin{array}{c}\text { Depth (meters below the } \\
\text { surface) }\end{array}$} & $\mathrm{H}$ & m & 780 & 835 & $600-1,000$ & 1,700 & 3,400 \\
\hline \multicolumn{2}{|c|}{ Major principal stress } & $\sigma 1$ & $\mathrm{MPa}$ & 41 & 41 & $41(*)$ & $52\left(^{*}\right)$ & 85 \\
\hline \multicolumn{2}{|c|}{ Intermediate principal stress } & $\sigma 2$ & $\mathrm{MPa}$ & 24 & 20 & $31(*)$ & $41(*)$ & 59 \\
\hline \multicolumn{2}{|c|}{ Minor principal stress } & $\sigma 3$ & $\mathrm{MPa}$ & 20 & 12 & $22(*)$ & $30(*)$ & 59 \\
\hline \multicolumn{2}{|c|}{ Stress ratio } & $\sigma 1 / \sigma 3$ & & 2.05 & 3.42 & 1.86 & 1.73 & 1.44 \\
\hline \multicolumn{2}{|c|}{ Pore pressure } & $\mathrm{Pp}$ & $\mathrm{MPa}$ & 0 & 0 & 0 & 0 & 61 \\
\hline \multicolumn{2}{|c|}{ Tensile strength } & $\mathrm{T}$ & $\mathrm{MPa}$ & 9 & 7 & 12 & 14 & 7 \\
\hline \multicolumn{2}{|c|}{ Poroelastic parameter } & $\mathrm{H}$ & & 0.5 & 0.5 & 0.5 & 0.5 & 0.23 \\
\hline \multirow{3}{*}{$\begin{array}{l}\text { Breakdown } \\
\text { pressure }\end{array}$} & Field result & $\mathrm{Pb}$ & $\mathrm{MPa}$ & 43 & 35 & 33 & N/A & 48 \\
\hline & $\begin{array}{c}\text { Poroelastic } \\
\text { estimation(**) }\end{array}$ & $\mathrm{Pb}$ & $\mathrm{MPa}$ & 40 & 26 & 64 & 85 & 46 \\
\hline & $\begin{array}{c}\text { Elastic } \\
\text { estimation }(* *)\end{array}$ & $\mathrm{Pb}$ & $\mathrm{MPa}$ & 40 & 26 & 64 & 85 & 38 \\
\hline
\end{tabular}

\subsubsection{Fluids and proppants}

The use of fracturing fluids and proppants is another aspect that can affect the hydraulic fracturing performance. In this regards, the most common fluid used in cave mining and petroleum is water, which provides an easier handling and application during the injection at high pressure into the drillhole or wellbore. In addition, viscous fluids like gel, are also used to obtain some positive impacts related to reduce leak off because of its ability to sustain fracture propagation with time, which is particularly useful in the presence of faults or major pre-existing structures or natural fractures (see Figure 8). The use of viscous fluids is also useful to generate more extended but flat hydraulic fractures (Ishida et al. 2004). 


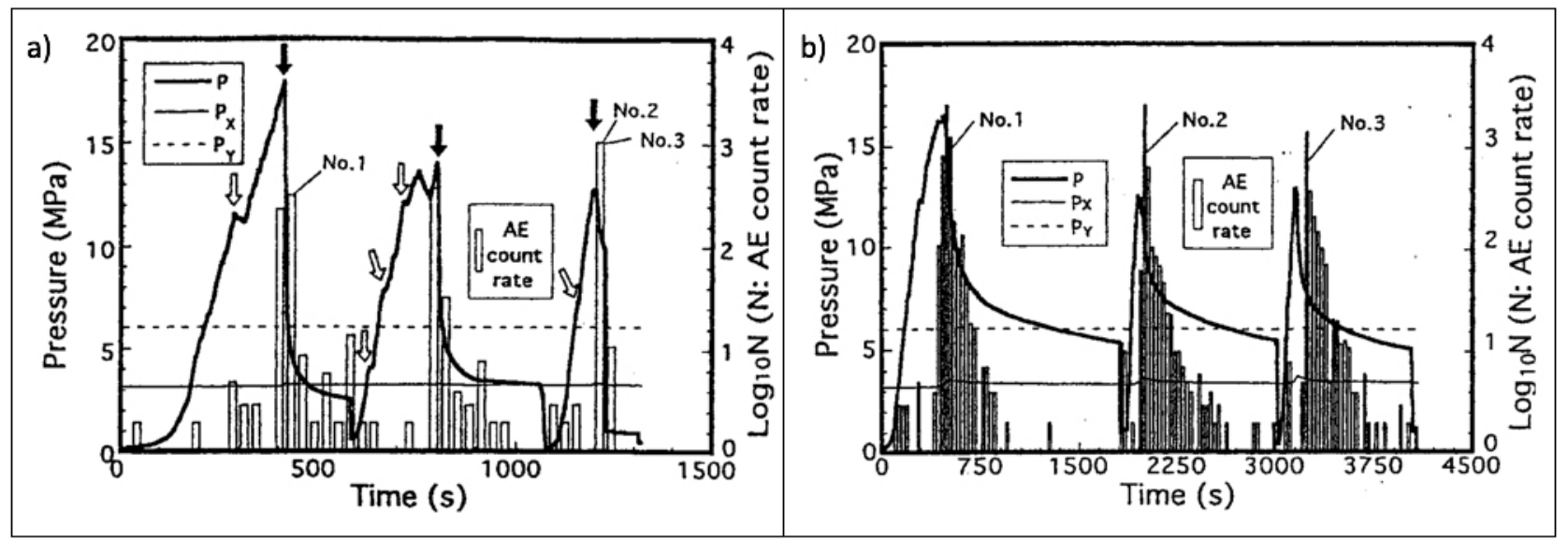

Figure 8 Impact of using viscous fluids in hydraulic fracturing. Laboratory experiment using a cube of $19 \mathrm{~cm} \times$ $19 \mathrm{~cm} \times 19 \mathrm{~cm}$, horizontally loaded Px = $3 \mathrm{Mpa}$ and Py = $6 \mathrm{MPa}$. Results of axial pressure Pz versus time for a) Water injection and b) oil injection (Ishida et al. 2004)

In addition, proppants are commonly found in petroleum applications to enhance hydraulic fracturing performance. Sand is the most common proppant, and its application is to be able to keep the hydraulic fractures open, thereby preserving the effect of increasing permeability, which is an important outcome in the context of production (see Figure 9). Regardless it is not evident the positive impact of using proppants in cave mining, it is possible to explore additional effects of keeping fractures open, in terms of cave performance.

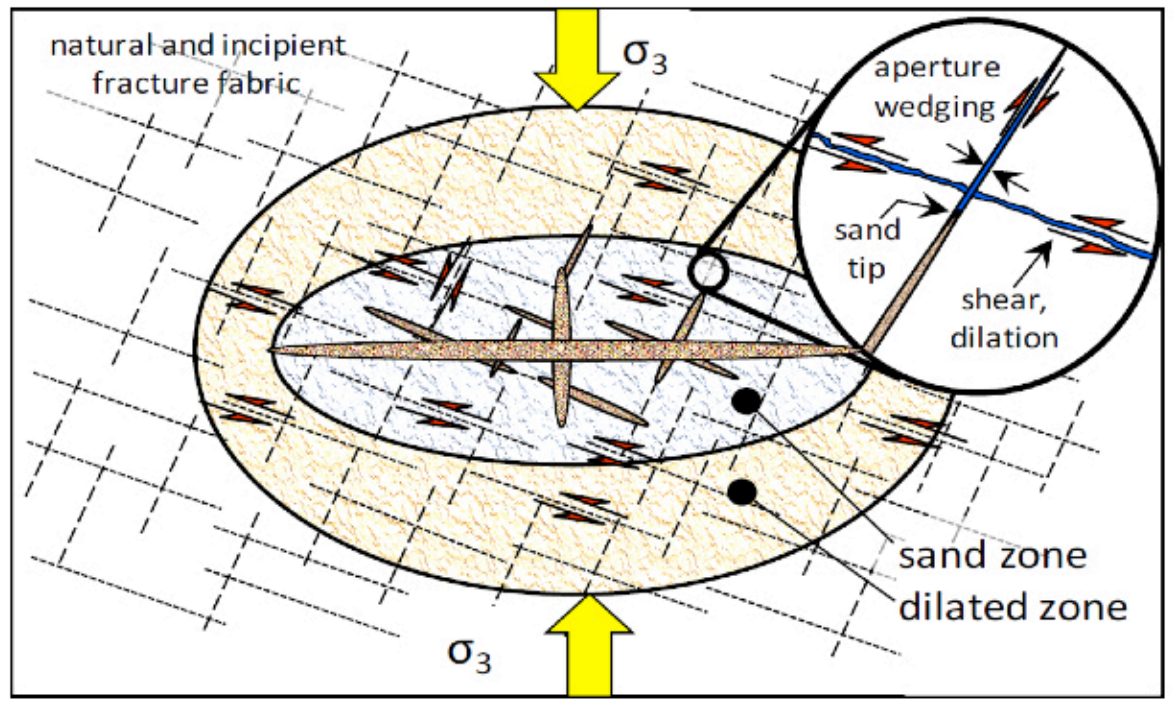

Figure 9 Effect of sand in hydraulic fractures (Dusseault 2011)

\subsubsection{Fracture re-orientation}

Another important aspect is related to the re-orientation of hydraulic fractures, which depends on several conditions. The most evident is the orientation of the drillhole in relation to the in situ principal stresses, given the fractures tend to propagate aligned with the major principal stress (Brumley \& Abbas 1996). 
Fracture re-orientation can be produced using perforations (casing) or drillhole notchs (open hole), which effectively prescribe the initial fracture orientation, which effect is propagated until a distance equivalent to 1 times drillhole diameter (Behrmann 1991). This effect was used by He et al. (2016b) to propose the concept of 'prescribed hydraulic fractures', which are fractures oriented in a different direction than the major principal stresses, creating a network of discontinuities that in principle would be beneficial for cave propagation. This conceptual design assumes the previous allocation of flat fractures aligned with the principal major stress, and then an oblique borehole to create additional reoriented fractures (see Figure 10). In theory, hydraulic fractures from the oblique borehole should align with the local stress regime created by the pre-located fractures above and below (stress shadow effect). Regardless the implementation of this specific proposal can be costly in terms of numbers of boreholes, it provides some interesting fundamental concepts based on fractures re-orientation.

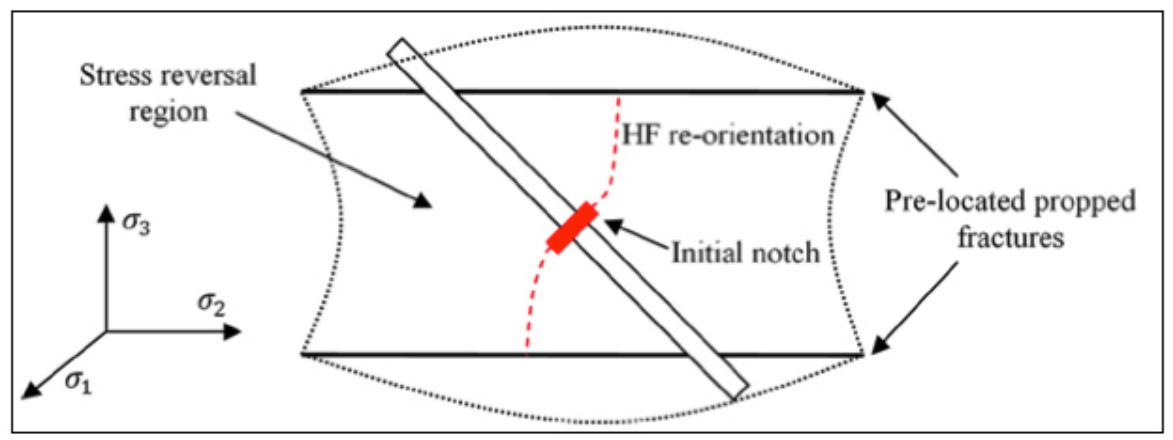

Figure 10 Concept of prescribe hydraulic fractures (He et al. 2016b)

\subsubsection{Stress shadow effect}

Stress shadow is being extensively studied in the petroleum industry over the time (Sneddon 1945), given its impact in the hydraulic fracturing performance. In the case of Petroleum stress shadow effect can be negative, producing a less effective impact on permeability enhancement (Bayer et al. 2016).

Stress shadow is the increasing of local stress field due to fluid net pressure, following fracture propagation. Perpendicular to the fracture tensions increase more and potentially can rotate the local stress field. Figure 11 shows an example of induced stress around a hydraulic fracture, using the elasticity solution by Sneddon \& Elliot (1946) in two-dimensions under a plane strain condition, as function of normalised distance at different positions along the fracture extension. This result shows that perpendicular and closer to the fracture; the induced stress effect is maximum, and from a normalised distance of 0.5 , equivalent to $50 \%$ of the radius of fracture propagation, stress shadow effect is still $90 \%$ of the maximum value of induce stress.

Empirical results of Pilar Norte and Reservas Norte mining areas of El Teniente, show a range of fracture propagation between 17 and $30 \mathrm{~m}$, in a Dacite rock type with UCS of $151 \mathrm{MPa}$ and very competent rockmass of GSI 75-90 (see Figure 12). Given these empirical results and elastic results of Figure 10, it is possible to argue that a stress shadow effect is still high in a range of 8-15 $\mathrm{m}$ of fracture propagation.

This induced stress effect has important impacts that can be better understood when fractures interact between them. Figure 13 shows a numerical simulation to estimate propagation paths of two parallel fractures under isotropic (hydrostatic) and anisotropic in situ stress field. As it can be seen, fracturepropagation path is curved due to the stress shadow effect, because of the rotation of the local stress field. Because of this result, it is expected to have a networking fracturing in the neighbourhood of the drillholes and a flat fracturing far away (see Figure 14 and 15). 

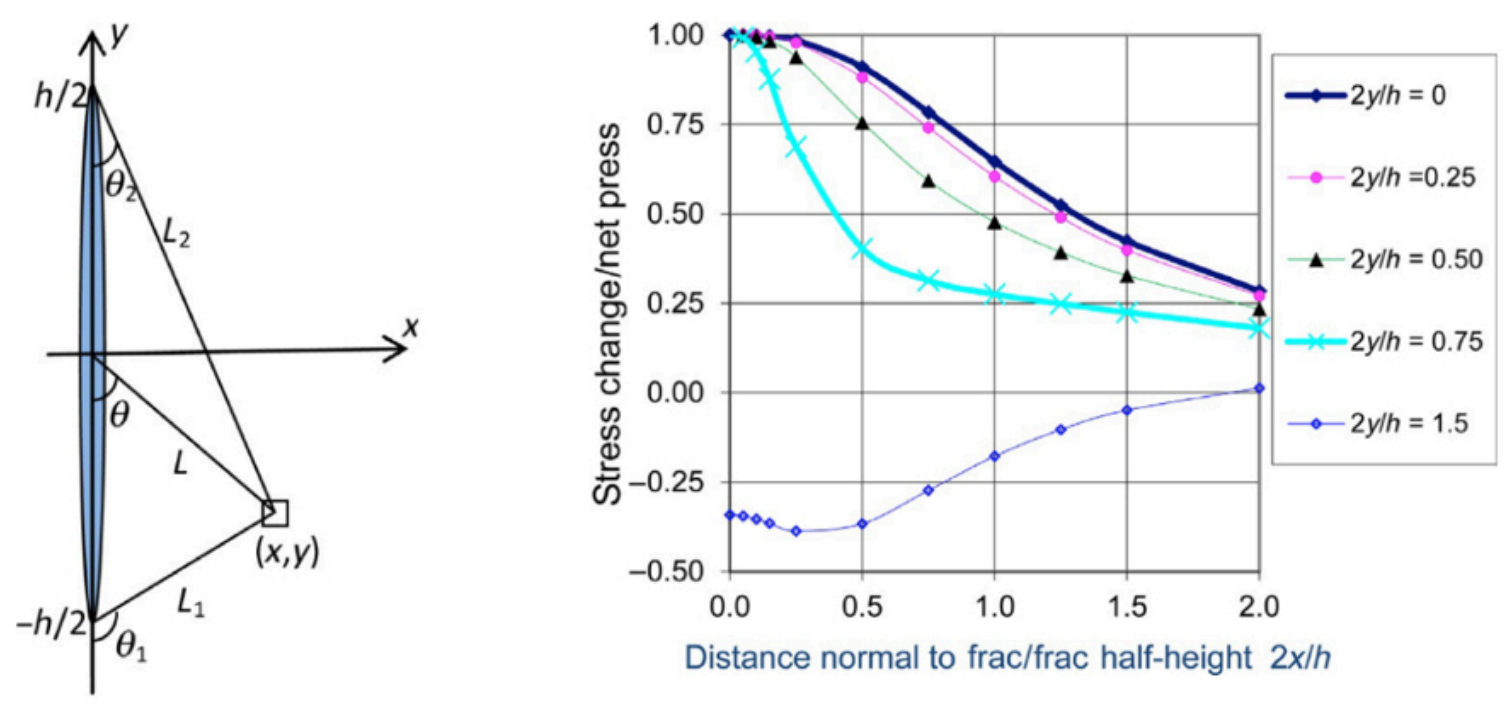

Figure 11 Elastic estimation of the stress shadow effect as the increasing of local stress near the fracture (Yew \& Weng 2015)

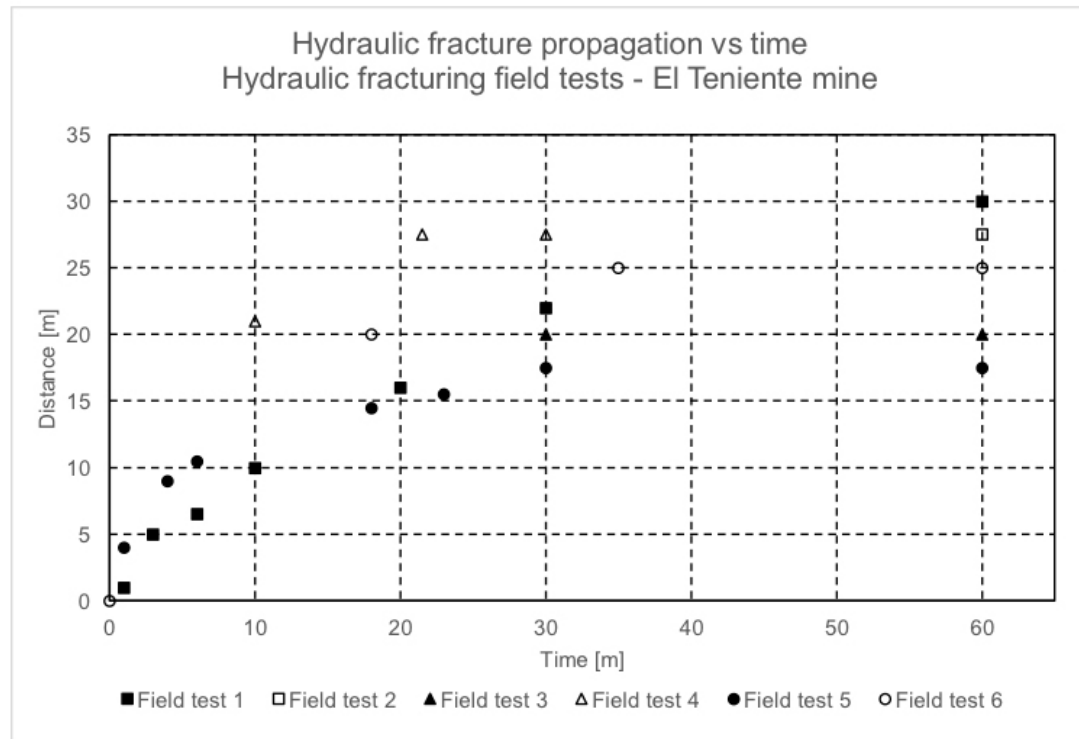

Figure 12 Empirical results of hydraulic fracture propagation versus time in mine areas of Pilar Norte and Reservas Norte, El Teniente mine. (modified from Rojas \& Balboa 2017)

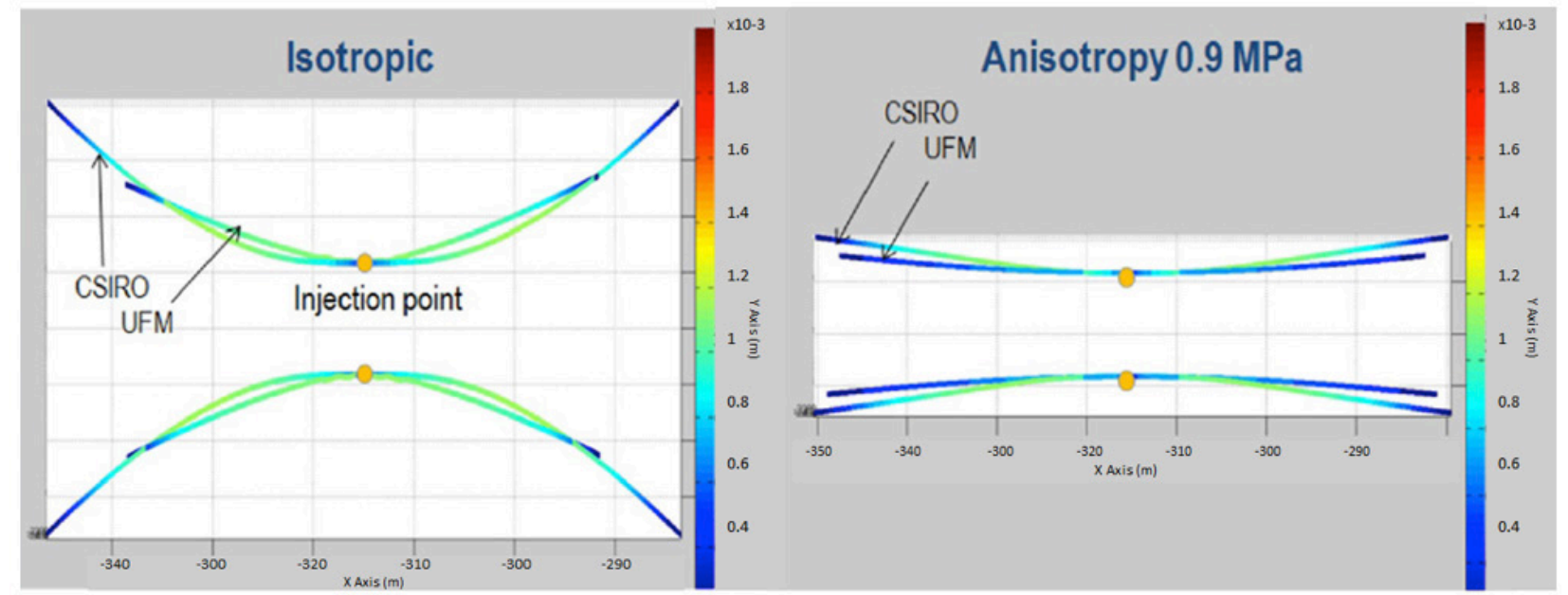

Figure 13 Numerical simulation of the stress shadow effect under isotropic and anisotropic In Situ stress field (Yew \& Weng 2015) 


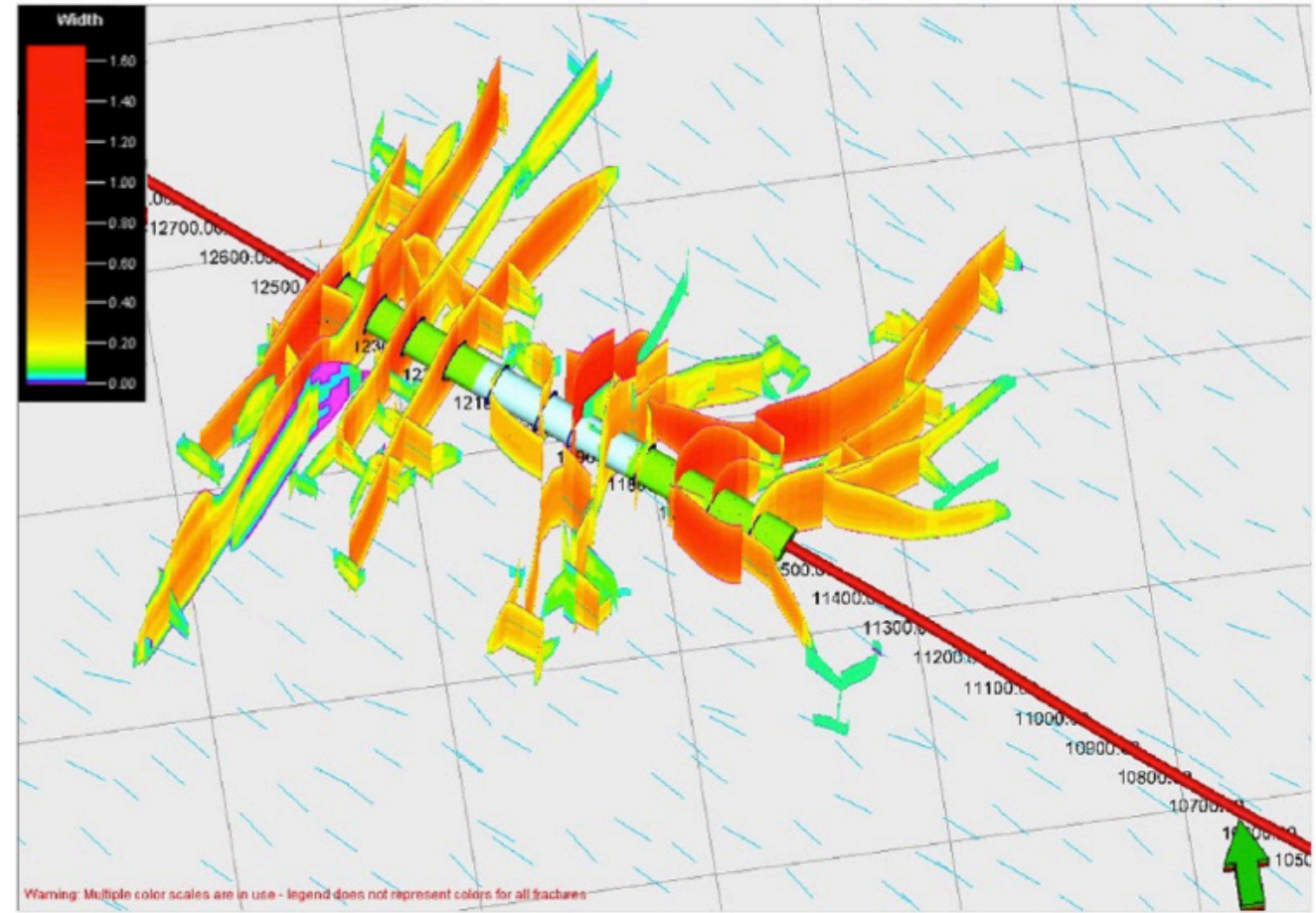

Figure 14 Simulation of a multistage hydraulic fracturing showing network fracturing near the hole, and flatter fracturing far away due to stress shadow effect (Yew \& Weng 2015)

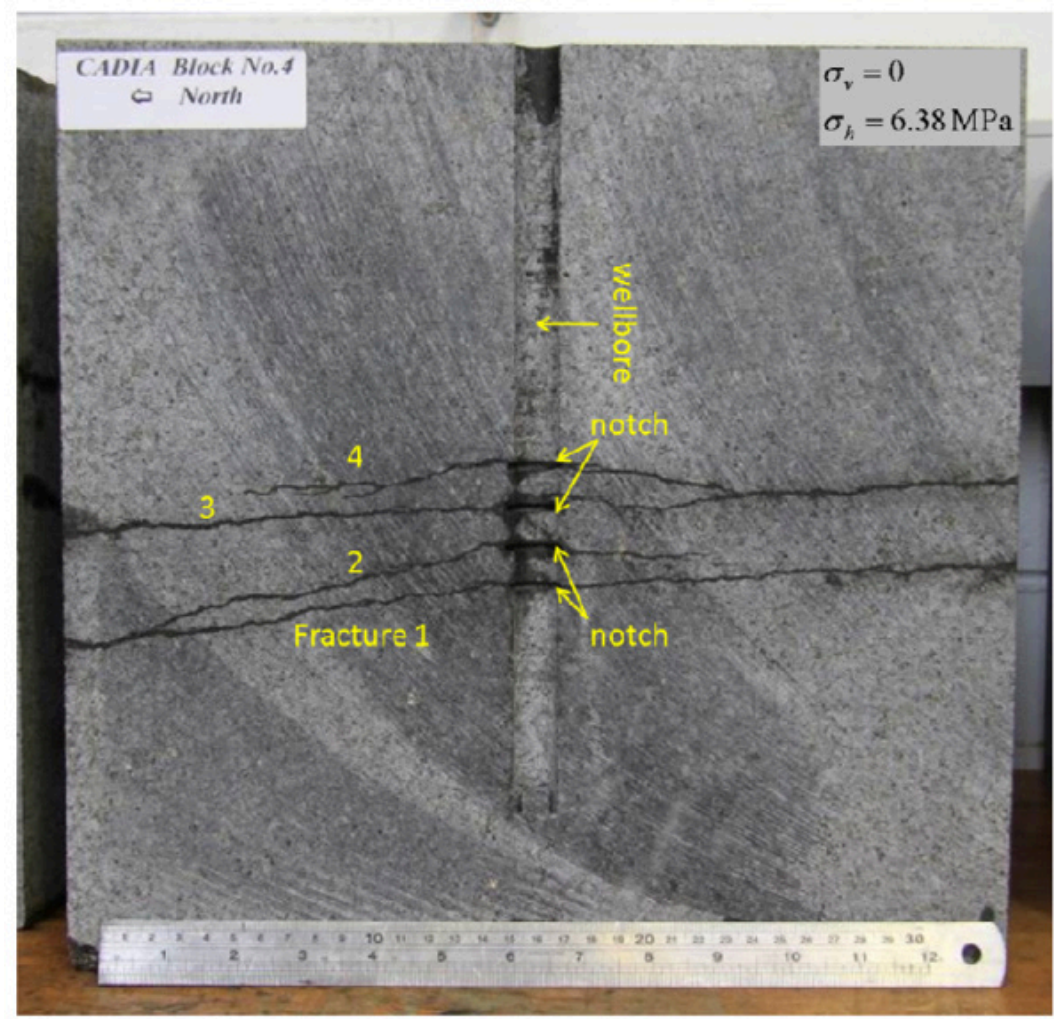

Figure 15 Experimental hydraulic fracturing results for a block with a fracture spacing of $15 \mathrm{~mm}$, vertical of 0 $\mathrm{MPa}$, and horizontal loads of 6.38 MPa (Bunger et al. 2011)

\subsection{Opportunities to improve a hydraulic fracturing design in cave mining}

Given the successful application of hydraulic fracturing in petroleum, a first option of improvement is to just implement the same approach based on drillholes from the surface to inject high pressure water to cover the rockmass volume. This implementation also includes cased holes and perforations to inject the water at different levels, and higher pumping rates of 10 times than used in cave mining. Eventually, the 
water can be mixed with proppants (sand) to keep fractures open and increase the fracture extension. The expected result can deliver exactly what Petroleumachieves, but it is important to check how this is aligned with the target looked for in cave mining.

Petroleum industry looks for to increase in situ permeability as main objective for using fracturing, which brings downgrading of the rockmass because of additional fractures. Hydraulic fracturing was applied in cave mining to downgrade the rockmass but looking for a different effect in terms of seismic response, cave propagation or fragmentation (see table 1). Regardless, current practice in mining shows that optimisation process is carried out following exactly in the same way as it is in Petroleum, in terms of fracturing spacing to avoid stress shadow effects (Belyadi et al. 2019) to maximise the extension of ideal flat fractures (see Figure 16a). Petroleum implementation intent to minimise the stress shadow effect because of the negative impact in creating more fractures along the wellbore, to get connectivity with the resource (oil). This is an important point, because in cave mining it is more important the creation of a network of fractures into the rockmass, in which stress shadow effect can play a role.

Regardless the fundamental knowledge is the same, the optimisation process for a hydraulic fracturing application in cave mining should not follow the same criteria as used for Petroleum hydraulic fracturing. In cave mining is more important the creation of dendritic fracturing rather than flat fractures to facilitate cave performance (see Figure 16b), which can be done taking advantage of the stress shadow effect during the design process.

Then, the proposed objective for optimising the process should be maximise the dendritic fracturing and the volume preconditioned by each hole, which address the distribution of boreholes.

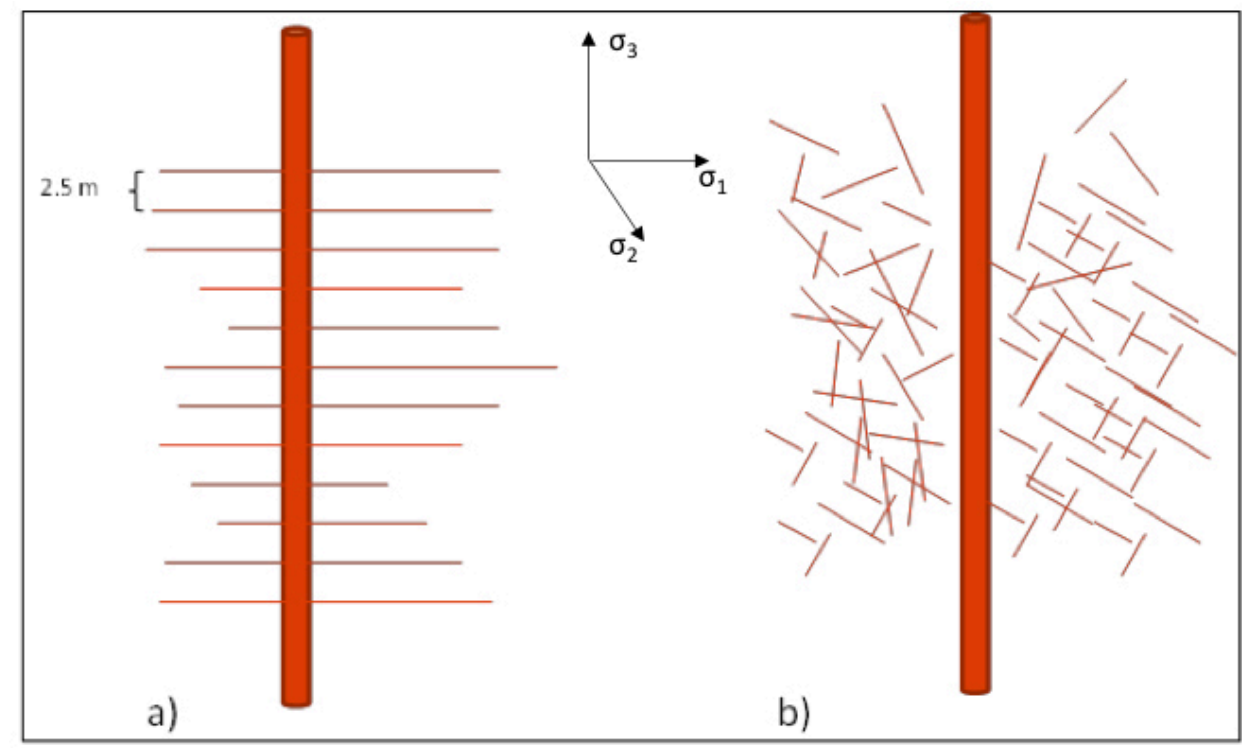

Figure 16 Types of fracturing obtained that can be looked for using hydraulic fracturing. a) Idealization of flat fractures following a sequence of hydraulic fracturing every $2.5 \mathrm{~m}$, b) Ideal result maximising dendritic fracturing and volume to increase cave performance (seismic response, cave initiation/propagation and fragmentation)

The ideal outcome proposed in Figure 16b, can be pursued by taking advantage of the stress shadow effect and sequence of the hydraulic fracturing. He et al. (2016) proposed the allocation of initial flat fractures to generate a local rotated stress field, and then another set of hydraulic fractures that will follow different orientation, using an oblique borehole (see Figure 17). There are evident operational complexities to implement the second stage, because of the damage generated along the borehole after first stage, and the precision required to allocate an oblique borehole with respect the stress field in the surrounding rockmass. Also, the dendritic volume is limited by the prescribed fractures in red dashed lines in Figure 17. Despite of these operational and design limitations, which they are still conceptual, the principles are useful and innovative in the context of current applications of hydraulic fracturing in cave mining. 


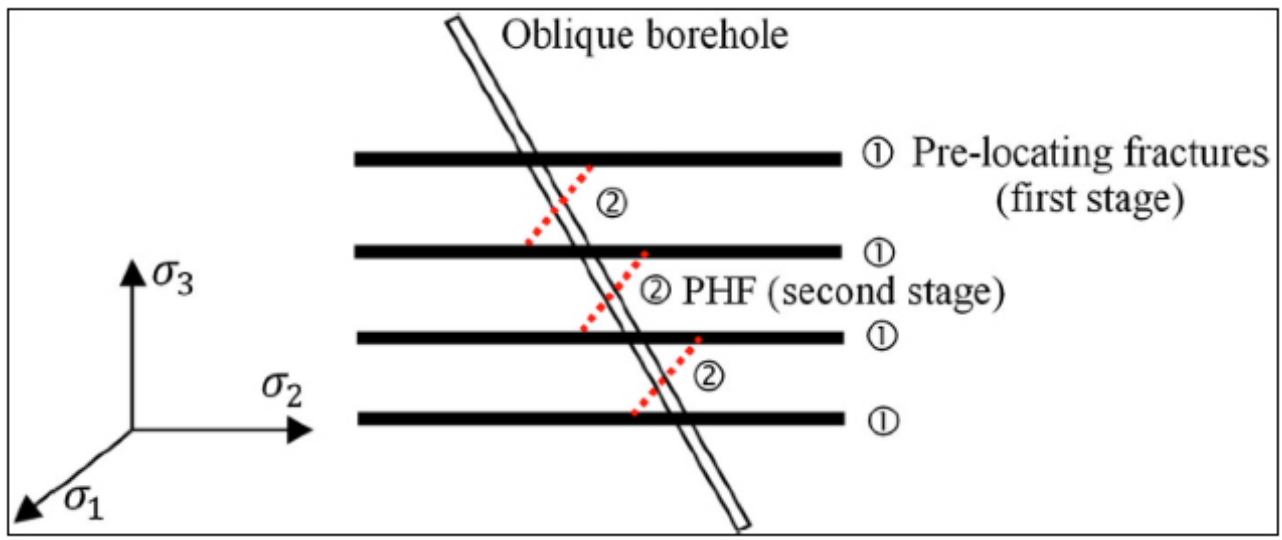

Figure 17 Prescribe hydraulic fractures based on 2 stages and an oblique borehole. Stage 1 of pre-location of flat fractures. Stage 2 of prescribed fractures oriented to stage 1 fractures due to stress shadow (He et al. 2016a).

With the purpose to pursue the optimisation principles proposed in this work (maximise dendritic fracturing and preconditioned volume), and a better operational implementation, it is proposed a combination of 2 stages to, first create a different local stress condition and secondly a sequence of hydraulic fractures. First stage should allocate 2 hydraulic fractures spaced in a range of 8-15 $\mathrm{m}$ to still generates a strong stress shadow effect (see section 2.1.4), which leave an extension in between less damaged. Second stage consists of the allocation of additional hydraulic fractures in between, following a convergence sequence to the middle point (See Figure 18). These 2 stages can be iterated to cover the whole borehole.

From the operational point of view, these 5 steps in this 2 stages, can be implemented with multiple packers for more operational control of the process, and the use of proppants for stage 1 can be used to keep the fractures open for additional stress shadow effect.

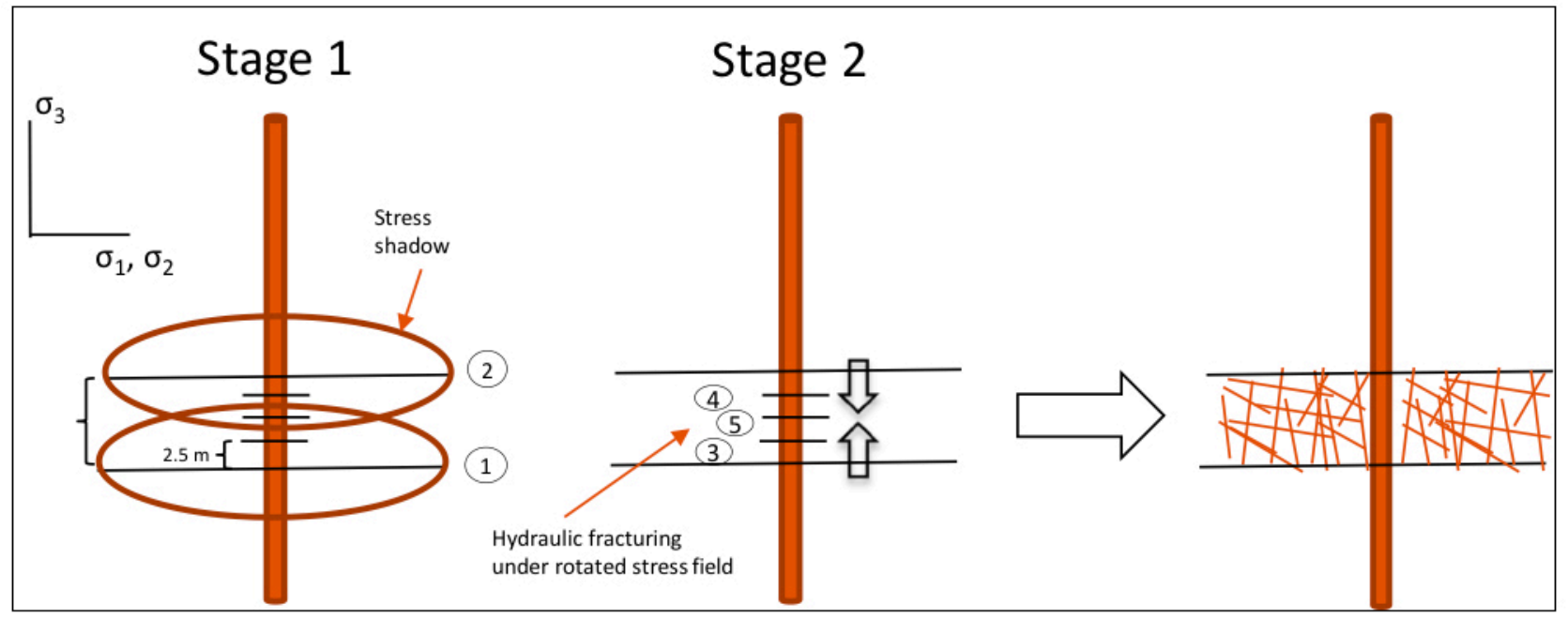

Figure 18 Proposed improvement in two stages, to maximise stress shadow effect to create network/dendritic fracturing to increase cave performance

\section{Conclusions}

Hydraulic Fracturing is increasingly becoming an essential enabling tool in deep hard rock cave mining, and some of the current HF practices used in the Petroleum industry offer an opportunity to improve the cave mining HF processes. Notwithstanding this trend, the principal author and through his applied and part-time PhD research is of the opinion about the lack of research in hydraulic fracturing to produce the type of fracturing required for a better cave performance: better seismic response, cave initiation/ propagation and fragmentation. Notably, the ability to replicate successful is not completely understood, to obtain expected results in different geotechnical environments. 
In this regard, stress shadow effect provides an opportunity to optimise a hydraulic fracturing design to generate a better network (dendritic) fracturing, which can be applied with the right sequence and combination of proppants and/or viscous fluids. This conceptual view, which combines petroleum fundamental concepts and recent research in cave mining, offer the potential to explore more options for optimisation more likely to be operationally implemented.

It is a matter of research the limitations of such approach under high stress and hard rock conditions, to understand how deeper environments can affect the performance, and how this can be mitigated with the right hydraulic fracturing design.

\section{Acknowledgement}

The opportunity for the principal author to undertake a part-time and applied PhD through the Sustainable Minerals Institute of the University of Queensland and with support from BHP is greatly acknowledged. This paper benefits from the knowledge that has evolved through work on application of pre-conditioning by cave mining companies notably, Codelco, Newcrest and Northparkes and by several Petroleum companies hosting many petroleum reservoirs applying hydraulic fracturing in the Texas Gulf Coast. Some of the theoretical concepts discussed in this paper are from regular discussions with a University of Queensland based advisory team comprised of Dr Ray Johnson, Well Engineering \& Production Technology, Dr Zhongwei Chen, Senior Lecturer of Mining, and Eduardo Rojas, Geomechanics Director of Codelco El Teniente in his capacity as an industry advisor of this research.

\section{References}

Bayer, S, Wunderle, M, Araujo, E, Alcalde, R, Yao, C, Suhy, F, Jo, T, Bases, F, Sani, A, Ma, Y, Bansal, A, Peterson, E, Goudge, R, Awasthi, A \& Bhatia, M 2016, 'Geological and geomechanical modelling of the Haynesville Shale: A full loop for unconventional fractured reservoirs', Unconventional Resource Technology Conference, Texas.

Behrmann, L \& Elbel, J 1991, 'Effect of perforations on fracture initiation', Journal of Petroleum Technology, vol. 43, no. 5.

Belyadi, H, Fathi, E \& Belyadi, F 2019, Hydraulic Fracturing in Unconventional Reservoirs. Theories, Operations, and Economic Analysis - First Edition, Elsevier.

Brumley, J \& Abbas,H 1996, 'Hydraulic fracturing of deviated wells: interpretation of breakdown and initial fracture opening pressure', Society of Petroleum Engineers, Columbus.

Brzovic, A \& Gonzalez, R 2019, 'Evidence of a consistent process of rock fracturing during material flow within ore columns 25 Years of fragmentation experience at the El Teniente Mine', 53rd US Rock Mechanics/Geomechanics Symposium, New York.

Bunger, A, Jeffrey, R, Kear, J, Zhang, X \& Morgan,M 2011, 'Experimental investigation of the interaction among closely spaced hydraulic fractures', 45th US Rock Mechanics/Geomechanics Symposium, San Francisco.

Catalan, A, Onederra, I \& Chitombo, G 2017, 'Evaluation of intensive preconditioning in block and panel caving - Part I, quantifying the effect on intact rock', Mining Technology, vol. 126, no. 4, pp. 209-220.

Catalan, A \& Suarez, C 2010, 'Geotechnical characterisation - Cadia East panel caving project, New South Wales, Australia', Proceedings of the Second International Symposium on Block and Sublevel Caving, Perth, pp. 371-387.

Deeg, W 1998, 'Hydraulic Fracture-Initiation in Deviated or Horizontal Openhole Wellbores', Society of Petroleum Engineers Inc./ISRM, Eurock '98, Trondheim.

Detournay, E \& Cheng, A 1993, 'Fundamentals of Poroelasticity', Comprehensive Rock Engineering: Principles, Practice \& Projects, Volume 2: Analysis and Design Methods, pp. 113-171.

Dusseault, M \& McLennan,J 2011, 'Massive Multi-Stage Hydraulic Fracturing: Where are we?', 45th Rock Mechanics/ Geomechanics Symposium, San Francisco, California. 
He, Q, Suorineni, F T \& Oh, J 2016a, 'Review of Hydraulic Fracturing for Preconditioning in Cave Mining', Journal of Rock Mechanics \& Rock Engineering, vol. 49, pp. 4893-4910.

He, Q, Suorineni, F T \& Oh, J 2016b, 'Strategies for Creating Prescribed Hydraulic Fractures in Cave Mining', Journal of Rock Mechanics \& Rock Engineering, vol. 50, pp. 967-993.

Hormazabal, E, Villegas, F, Rovira, F \& Carranza-Torres, C 2010, 'Geomechanical evaluation of macro-block caving options using 3D numerical modelling at Chuquicamata underground project in Chile', Proceedings of the Second International Symposium on Block and Sublevel Caving, Perth, pp. 469-482.

Ishida, T, Chen, Q, Mizuta, Y \& Roegiers, J-C 2004, 'Influence of fluid viscousity on the hydraulic fracturing mechanism', Journal of Energy Resources Technology, vol. 126 / 199.

Jaeger, J, Cook, N \& Zimmerman,R 1976, Fundamentals of Rock Mechanics, Blackwell Publishing.

Jarufe, J \& Vasquez, P 2008, 'Mine-Scale 3D Stress Model for the New Mine Level Project, El Teniente, Codelco, Chile', Proceedings of the First Southern Hemisphere International Rock Mechanics Symposium, Perth.

Jeffrey, R, Van As, A, Zhang, X, Bunger, A \& Chen, Z 2010, 'Measurement of hydraulic fracture growth in a naturally fractured orebody for application to preconditioning', Proceedings of the Second International Symposium on Block and Sublevel Caving, Perth, pp. 647-662.

Jonsson, K \& Martinsson, J 2018, 'Evaluating the effect on seismicity of a hydraulic fracturing trial using Bayesian data analysis', Caving 2018, Vancouver.

Pardo, C \& Rojas, R 2016, 'Selection of exploitation method based on the experience of hydraulic fracture techniques at the El Teniente mine', 7th International Conference \& Exhibition on Mas Mining, Sydney.

Rojas, E 2018, 'Undercut rates and cave rules presentation', Internal Caving Workshop, Phoenix.

Rojas, E \& Balboa, S 2017, 'Management of seismic risk in high stress conditions, El Teniente mine', 9th Symposium on Rockbursts and Seismicity in Mines, Santiago.

Sainsbury, B, Sainsbury, D \& Carroll, D 2018, 'Backanalysis of PC1 cave propagation and subsidence behaviour at the Cadia East mine', Caving 2018, Vancouver.

Sneddon, E 1946, 'The distribution of stress in the neighbourhood of a crack in an elastic solid', Proc R Soc Lon, pp. $229-260$.

Talu, S, Van As, A, Seloka, W \& Henry, R 2010, 'Lift 2 North extension cave performance', Proceedings of the Second International Symposium on Block and Sublevel Caving, Perth, pp. 407-421.

Windsor, C, Cavieres, P, Villaescusa, E \& Pereira, J 2006, 'Rock stress tensor measurements at El Teniente Mine, Chile', In-Situ Rock Stress International Symposium on In-Situ Rock Stress, Trondheim.

Yew, C \& Weng,X 2015, Mechanics of hydraulic fracturing - Second Edition, Elsevier.

Zham, C \& Enderlin, M 2010, 'Characterisation of rock strength in Cretaceous strata along the Stuart City Trend', Guld Coast Association of Geological Societies Transactions v 60, Texas, pp. 693-702.

Zhang, J \& Yin, S 2017, 'Fracture gradient prediction: an overview and an improved method', Petroleum Science, pp. $720-730$. 